\title{
Hydrogeochemical Signatures of Different Aquifer Layers in the Crystalline Basement of Oban Area (SE Nigeria)
}

\author{
A. S. Ekwere \\ Department of Geology, University of Calabar \\ E-mail: zerratta77@yahoo.com
}

A. Edet

Department of Geology, University of Calabar

Received: November 29, $2011 \quad$ Accepted: December 16, $2011 \quad$ Published: March 1, 2012

doi:10.5539/jgg.v4n1p90 URL: http://dx.doi.org/10.5539/jgg.v4n1p90

\begin{abstract}
The shallow and deep aquifer horizons of the crystalline basement of Oban massif of (SE Nigeria) were studied during the dry and wet seasons. The criteria were ascertaining hydrogeochemistry relative to seasonal and spatial variations across the study region. The results obtained show that major elements such as $\mathrm{Ca}, \mathrm{Mg}, \mathrm{Na}$ and $\mathrm{K}$ were higher in the shallow aquifers than in the deep aquifers, during the study period. The major anions $\mathrm{Cl}, \mathrm{SO}_{4}$, $\mathrm{HCO}_{3}$ and $\mathrm{NO}_{3}$ were higher in the deep aquifers compared to the shallow ones. Two water types were identified for both (shallow and deep) aquifers: $\mathrm{Ca} / \mathrm{Mg}-\mathrm{HCO}_{3}$ and $\mathrm{Ca} / \mathrm{Na}-\mathrm{Cl} / \mathrm{SO}_{4}$. Most of the water parameters considered was within the international limits for drinking and domestic purposes. Assessment by use of Sodium Absorption Ratio (SAR), percent Sodium (\% Na) and the Wilcox diagram reveal that the waters are suitable for irrigation purposes.
\end{abstract}

Keywords: Shallow aquifer, Deep aquifer, Seasonal variations, Hydrogeochemistry, Oban crystalline basement, SE Nigeria

\section{Introduction}

Hydrogeochemical studies have over the years played an essential role in interpreting mineralogical composition of the sub-surface and inherent conditions in most geological settings. However, this approach has produced more comprehensive interpretation when applied together with other Earth science studies such as structural geology, photo-geology, remote sensing as well as deep geophysics.

In contrast to the large amount of work aimed at quantifying the permeability of unconsolidated and sedimentary rocks, little work has been reported on igneous and metamorphic rocks. Norton and Knapp (1977) stated that the fact that minerals tend to form along the walls of fractures and in veins demonstrates that fluid flow in sub-surface systems is controlled by fracture distribution. The major factor that controls or increases the permeability of igneous and metamorphic rocks is weathering. The combination of near surface weathering and fracturing will increase the permeability by two or four orders of magnitude (Davies and De Weist, 1966 and Davis, 1969). In general these effects are apparent only within the first $20 \mathrm{~m}$ below the surface, but can extend down to as much as $100 \mathrm{~m}$ in tropical zones (Scheytt, 1997). Variations in groundwater geochemistry have also been shown to be related to the position of the aquifer units (Scheytt, 1997).

In basement terrains, there is a general belief that water exists in fractured rocks and overlying regolith and that such water is usually structurally controlled.

The study area (the Oban massif) forms part of the south-eastern basement complex of Nigeria, which lies between the Archaean cratons of west and central Africa. Recent and on going investigations within the study area notably Edet (1993), Edet et al., (1994), Edet et al., (1998), Okereke et al., (1998), Edet and Okereke (2005) Okereke et al. (1998), have led to the delineation of groundwater productive zones, quantitative and qualitative estimation of aquifer parameters within the massif. These have been expressed by interrelations between lineaments frequency and density of regolith development. These assessments have all been achieved based on remotely sensed data, aerial photos, deep geophysics, and geologic logs from exploration boreholes within the 
study area. This current research attempts to assess the hydrogeochemistry of the groundwaters relative to aquifer levels within the massif.

\section{Description of Study Area}

The Oban Massif lies between longitudes $8^{\circ} 00^{\prime} \mathrm{E}$ and $8^{\circ} 55^{\prime} \mathrm{E}$ and latitudes $5^{\circ} 00^{\prime} \mathrm{N}$ and $5^{\circ} 45^{\prime} \mathrm{N}$ covering an area of about $8,740 \mathrm{~km}^{2}$ (Edet et al., 1998), Figure 1. This vast crystalline basement complex is characterised by isolated hills attaining a maximum height of about $1,200 \mathrm{~m}$ above sea level at locations on the eastern axis of the massif (Ayi, 1987). The topography exhibits sharp undulations with v-shaped valleys being typically forested at the highest peaks. The massif is well drained, controlled by weathered zones, fractured and jointed areas, coursing in two directions: southwards (seawards) and northwards to join the upper course of the Cross River in the Ikom depression.

The study area is characterized by a tropical climate with two distinct seasons: wet and dry. The wet season spans from May to October, while the dry extends from November to April. The general temperature trend for the study area is high with negligible diurnal and annual variations. The average monthly temperature in the area ranges from 29 to $34{ }^{\circ} \mathrm{C}$. A mean annual rainfall of about $2,300 \mathrm{~mm}$ have been reported for the area, with annual mean daily relative humidity and evaporation of $86 \%$ and $3.85 \mathrm{~mm} /$ day, respectively (CRBD, 2008). The regional run-off coefficient of the study area is in the order of $0.21-0.61$ and is due to topography and evaporation, (Petters et al., 1989).

\subsection{Geologic and Hydrogeologic Setting}

The Oban massif forms part of the huge spur of the western elongation of the Cameroon Mountains into the Cross River plains of south-eastern Nigeria (Ekwueme, 2003). Rahman et al. (1981) reported the rocks of the Oban massif to be dominated by: (1) locally migmatitic and shared gneissic rocks, paraschists, phyllites, metaconglomerates and quartzites, amphibolites and metadolerites, foliated pegmatites and aplites, pyroxenites, etc, (2) older synkinematic to late-kinematic intrusive series comprising different rock types such as meladiorites, granodiorites, adamellites to granites and weakly foliated to unfoliated pegmatites, aplites and quartz veins, (3) unmetamorphosed dolerites to microdioritic intrusives. These rock series exhibit variations across the sectors of the massif.

In summary, the Oban massif is described as being underlain by highly deformed Precambrian crystalline rocks, mainly granites, gneisses and schists. Theses rocks exhibit varying degrees of weathering across the massif. They are intruded by pegmatites, granodiorites, diorites, tonalites, monzonites, charnockites and dolerites (Ekwueme, 1990).

Based on a regional hydrogeological differentiation by Petters et al. (1989), the study area has been identified to belong to the basement complex province of the Cross River area of south-eastern Nigeria. Okereke et al. (1998) describe the Oban massif to be a three layer hydro-geolectric stratigraphic model composed of:

- a top unsaturated clayey sand (lateritic);

- middle gravelly sand and decomposed bedrock and;

- fresh bedrock (fractured).

The occurrence of groundwater in the study area has been established to be controlled by structural discontinuities such as fractures, joints, fissures and regolith, (Petters et al., 1989; Edet 1993; Edet et al., 1994). Rates and levels of recharge to porous aquiferous media in the study area, suffer impedance due to the top lateritic cover characteristic of the area, Petters et al. (1989). This is attributed to the high clay contents of these lateritic top soils, hence their low permeability.

A low to moderate lineament density has been ascribed to the Oban massif (Edet et al., 1994). This reflects on the depth and extent of weathering profiles and consequently their groundwater potential. There is no general water table for the area, due to the variability of structural and geological controls. However groundwater generally occurs under water table conditions across the massif.

Edet and Okereke, (2005) estimated the water bearing formations of the Oban massif to have a thickness of about 5-140 m. Okereke et al. (1998) employing Schlumberger electrical soundings and Werner profiling measurements, reported a $5 \mathrm{~m}$ average thickness for the dry overburden and aquifer components between 15-70 $\mathrm{m}$. These layers overly highly resistive fresh bedrock. Groundwater sources from the basement are few, a scenario ascribed to the level of uncertainty and cost of groundwater exploration in the area. Aquifer parameters from the study area are reported in Table 1. Lithologic logs show the main rock types (e.g. gneisses, schists, granites, granodiorites, quartzites and amphibolites) revealing four to six layers across the massif. These layers 
represent different degrees of weathering processes. Representative sections (A-A' and B-B', Figure 1) across the area, based on drilled data, are presented in Figures $2 \mathrm{a}$ and $\mathrm{b}$.

Two basic aquifer units were identified and boreholes penetrated these layers at different levels across the massif. The aquifers are classified as shallow and deep aquifers relative to depth from surface with respect to the study area. The shallow aquifer boreholes were those with a maximum drilled depth of less than $15 \mathrm{~m}$, hand dug and constituting about $60 \%$ of the total number of sampled bores. The deep wells were those drilled at depths greater than $15 \mathrm{~m}$, extending up to $30 \mathrm{~m}$ and beyond representing the remaining $40 \%$ of sampled bores.

The deep aquifer boreholes were mechanically drilled and usually hand pump or motorized pump fitted. This scenario will hence entail the transfer of groundwater between these seemingly successive layers of different degrees of cross-cutting and depth of weathering. The fractures and lineaments act as conduits of groundwater from shallow aquifers to deeper levels. Data from drilled holes litho-sections were obtained for the borehole/deep wells as these were well documented by the government intervention agencies that were responsible for the drilling. Such information were poorly documented or lacking for the shallow hand dug wells, as they were drilled by the local population with no recourse for data documentation.

The drilled well in Oban town shows that the aquifer units are weathered gneissose units with depth between 5 and $10 \mathrm{~m}$. The aquifer layer at Abiati village spans between the second and third layers down the drilled section (3-9m) and is characterised by a granitic-gneissic lithology. At Aningeje village the aquifer layer is gneissic-granitic extending from 6 to $15 \mathrm{~m}$ down profile. These are for locations on the eastern sector of the massif.

For the western sector, drilled holes at Iko Essai shows a granitic-gneissic unit extending from about 9 to $20 \mathrm{~m}$ being the aquifer layer. At Ibogo village the aquifer layer is a micaceous-schistose layer extending from about 4 to $35 \mathrm{~m}$ down the profile. Lithologic $\log$ at Old Netim shows the aquifer layer to be granite-gneiss and biotite-granite-gneiss extending from 3 to $39 \mathrm{~m}$. Ayaebam has a biotite-gneissic aquifer unit (between 6 and 32 $\mathrm{m}$ depth), while at Obung village the aquifer unit is pegmatitic-micaceous-gneissic with a depth extent of about 3 to $39 \mathrm{~m}$ down hole.

Measured aquifer parameters are as presented in Table 2. Static water level was determined by the use of a water depth probe meter. Water levels for the open wells were determined for both dry and wet seasons. This was not possible for the boreholes as such information was only obtainable during borehole construction, prior to their sealing. Static water level varied across the massif through the seasons rising to surface at Camp IV, New Ndebiji and Igbofia in the wet season. The lowest depth of water was recorded at Oban at $6.20 \mathrm{~m}$ in the dry season.

\section{Physicochemical Characteristics}

The geochemical nature of groundwater may depend on the depth of flow paths reflecting effects of the weathered profile and cavity control at different horizons within sub-surface.

Aquifer units within the massif occur basically at two levels: within $15 \mathrm{~m}$ from the surface (shallow aquifers) and beyond $15 \mathrm{~m}$ down hole (deep aquifers). The shallow aquifers were mainly exploited by hand dug open wells, while the deep ones were mechanically drilled, and down hole pumps have been set up. The groundwaters exhibit both physical and chemical variations, from the shallow to the deep aquifers, with recognizable influences of the sampling season. Results of chemical analysis of sampled groundwaters are presented in Tables 3(a) and (b). Assessment of quality of data was accomplished by calculating the ion balance error using equation (1), Hounslow (1995):

$$
\text { Error of ion balance }=\frac{\sum \text { cations }- \text { Lanions }}{\sum \text { cations }+ \text { Eanions }}
$$

An error within limits of + or $-5 \%$ is tolerable. Approximately all water quality data for this study were within this range. A statistical summary of measured parameters are shown in Tables 4(a) and (b).

\subsection{Deep Aquifers}

Data from dry season sampling revealed groundwaters from deep aquifers/boreholes to exhibit: $\mathrm{pH}$ values between 5.08 and 6.34 , temperature ranging from 26 to $32{ }^{\circ} \mathrm{C}$, while electrical conductivity (EC) values are between 34.6 and $326 \mu \mathrm{S} / \mathrm{cm}$ and Total Dissolved Solids (TDS) from 22.18 to $208.97 \mathrm{ppm}$. In the wet season, $\mathrm{pH}$ values ranged from 6.27 to 8.65 , temperature from 26 to $30.4^{\circ} \mathrm{C}$, EC from 60 to $430 \mu \mathrm{S} / \mathrm{cm}$, while TDS values were between 40 to $570 \mathrm{ppm}$. 
Concerning the dry season sampling, chemical species such as $\mathrm{Ca}^{2+}, \mathrm{Mg}^{2+}, \mathrm{Na}^{+}$and $\mathrm{K}^{+}$presented concentrations in the order of $12.26-122.10 \mathrm{mg} / \mathrm{L}, 0.42-5.38 \mathrm{mg} / \mathrm{L}, 1.99-9.0 \mathrm{mg} / \mathrm{L}$ and $0.89-3.46 \mathrm{mg} / \mathrm{L}$ respectively. Anion analysis of these groundwaters revealed concentrations of $2.50-56.98 \mathrm{mg} / \mathrm{L} 1$ for $\mathrm{Cl}^{-}, 12.25-97.60 \mathrm{mg} / \mathrm{L}$ for $\mathrm{HCO}_{3}{ }^{-}, 1.09-564.10 \mathrm{mg} / \mathrm{L}$ for $\mathrm{SO}_{4}{ }^{2-}$ and $0.003-47.51 \mathrm{mg} / \mathrm{L}$ for $\mathrm{NO}_{3}{ }^{-}$. In the wet season, cation concentrations ranged between $7.06-60.11,0.27$ - 3.67, $1.76-5.71$ and $0.19-4.69$ for $\mathrm{Ca}, \mathrm{Mg}, \mathrm{Na}$ and $\mathrm{K}$, respectively (all values in $\mathrm{mg} / \mathrm{L}$ ). Anions ranged from $27.99-596.60,18.25-213.50,15.34-839.60$ and $0.09-10.04$ for $\mathrm{Cl}^{-}$, $\mathrm{HCO}_{3}^{-}, \mathrm{SO}_{4}{ }^{2-}$ and $\mathrm{NO}_{3}^{-}$respectively (all values in $\mathrm{mg} / \mathrm{L}$ ).

\subsection{Shallow Aquifers}

Groundwater samples collected from the shallow wells during the dry season show $\mathrm{pH}$ values ranging from 5.12 - 6.86, temperatures between 26 to $28^{\circ} \mathrm{C}$, EC values in the range of 24.8 to $622 \mu \mathrm{S} / \mathrm{cm}$ and TDS values between 15.90 and $398.72 \mathrm{ppm}$. In the wet season, $\mathrm{pH}$ values ranged from 5.94 to 7.69 , temperature was between 27 and $30{ }^{\circ} \mathrm{C}$, while EC values ranged from 80 to $580 \mu \mathrm{S} / \mathrm{cm}$ and TDS values were in the range 60 to $890 \mathrm{ppm}$. Chemical analysis of groundwater samples from the dry season had $\mathrm{Ca}^{2+}$ ranging from 9.00 to $135.20 \mathrm{mg} / \mathrm{L}$, $\mathrm{Mg}^{2+}$ from 0.45 to $5.59, \mathrm{Na}^{+}$from 1.16 to $4.55 \mathrm{mg} / \mathrm{L}$ and $\mathrm{K}^{+}$ranged from 0.54 to $5.92 \mathrm{mg} / \mathrm{L}$. Anion analysis for these samples revealed $\mathrm{Cl}^{-}$from $1.02-87.47 \mathrm{mg} / \mathrm{L}, \mathrm{HCO}_{3}{ }^{-}$ranged from 18.30 to $122.30 \mathrm{mg} / \mathrm{L}, \mathrm{SO}_{4}{ }^{2-}$ from 1.28 to $117.90 \mathrm{mg} / \mathrm{L}$ and $\mathrm{NO}_{3}{ }^{-}$from 0.009 to $45.89 \mathrm{mg} / \mathrm{L}$.

In the wet season, $\mathrm{Ca}^{2+}$ ranged from 6.04 to $97.14 \mathrm{mg} / \mathrm{L} \mathrm{Mg}^{2+}$ from 0.32 to $3.42 \mathrm{mg} / \mathrm{L}, \mathrm{Na}^{+}$from 2.45 to 7.00 $\mathrm{mg} / \mathrm{L}$ and $\mathrm{K}^{+}$ranged from 0.99 to $45.89 \mathrm{mg} / \mathrm{L}$. Anions showed concentrations values ranging from 22.14 to $308.70 \mathrm{mg} / \mathrm{L}$ for $\mathrm{Cl}^{-}$, from 12.14 to $384.30 \mathrm{mg} / \mathrm{L}$ for $\mathrm{HCO}_{3}{ }^{-}$, from 13.64 to $471.70 \mathrm{mg} / \mathrm{L}$ for $\mathrm{SO}_{4}{ }^{2-}$ and from 0.23 to $11.72 \mathrm{mg} / \mathrm{L}$ for $\mathrm{NO}_{3}^{-}$.

\section{Discussion}

For both shallow and deep wells the difference in the physical parameters and average temperatures are insignificant. The difference in $\mathrm{pH}$ values is also negligible. $\mathrm{pH}$ values close to 7 or higher are characteristic of deep wells and groundwaters of artesian origin (Langmuir, 1997).

Electrical conductivity (EC) and total dissolved solids (TDS) were higher for the shallow wells than the deep wells. The shallow wells are characterized by higher degree of regolith development and abundance of free ions in waters. This can be attributed to equilibrium between the water and soluble rock type (Hem, 1986).

Assessment of results from chemical analyses shows that concentration levels of the major elements are higher for the shallow wells than for the deep wells. These variations in the concentration levels could be attributed to high weathering levels and development of regolith as considered for shallow wells. Clay content decrease down hole due to weathering decreasing and the more open joints or fractures. With greater depth however, the joints are closed yielding less groundwater. Maturity of waters relative to resident times and history of travel along interconnected pore spaces also determine concentration levels of these mobile chemical species in shallow aquifers (Sears and Langmuir, 1982).

Concentration levels of anions are higher in the deep wells than in the shallow wells, with exception of $\mathrm{NO}_{3}{ }^{-}$ which is higher for the shallow wells. Nitrate concentrations can be used as an indicator of anthropogenic pollution. Levels of about $8.5 \mathrm{mg} / \mathrm{L}$ are considered to represent low level contamination (Hallberg, 1989). This could be interpreted for the groundwaters from shallow wells based on their proximity to surface anthropogenic inputs. Probable source of nitrate would be the use of fertilizers in farming and dumping of human and animal waste in the environment.

The noticeable anion content variation trend between shallow and deep waters, could be attributed to higher in-situ concentrations of chemical species in the waters of the deeper aquifers with longer resident times of water-rock interaction.

\subsection{Hydrochemical Facies}

Observations across the massif, shows that shallow groundwaters are diluted waters, slightly acidic with mean $\mathrm{pH}$ values of 6.02 , and belong mainly to the $\mathrm{Ca} / \mathrm{Mg}-\mathrm{HCO}_{3} / \mathrm{SO}_{4}$ facies, and in a lesser extent to the $\mathrm{Ca} / \mathrm{Mg}-\mathrm{SO}_{4} / \mathrm{HCO}_{3}$ water type. As the depth of aquifer increases the shallow groundwaters evolve to higher mean $\mathrm{pH}$ values of 7.17, become slightly alkaline and $\mathrm{Ca} / \mathrm{Na} / \mathrm{Mg}-\mathrm{HCO}_{3} / \mathrm{SO}_{4}$ type waters. The prevailing geochemical signatures of the groundwaters are $\mathrm{Ca}-\mathrm{HCO}_{3} / \mathrm{SO}_{4}$. This classification was also proposed by Langmuir (1997), and reflects the processes involved in chemical weathering of silicates and the common occurrence of calcium carbonate.

The apparently dominant $\mathrm{Ca} / \mathrm{Mg}-\mathrm{HCO}_{3}$ water type is defined as the normal alkaline group of water. Amadi (1987) describes this type of water as typical of Nigerian basement terrain with limited mixing, perhaps 
reflecting a primary stage of evolution of its groundwater system. A similar water type has been reported for the western basement complex of Nigeria by Elueze et al., (2004) and Tijani (1994). The chemical composition of this water type is ascribed to the dissolution of silicate minerals in the bedrock and aluminosilicates in the weathered regolith, Tijani (1994). In these waters, $\mathrm{Ca}^{2+}+\mathrm{Mg}^{2+}$ concentrations are higher than $\mathrm{HCO}_{3}^{-}$ concentrations. Such water type is believed to show permanent hardness with no bicarbonate hazard for irrigation (Naik et al., 2001).

\subsection{Irrigation Suitability}

The major characteristics of water that determine its suitability for irrigation purposes are: (i) total concentration of soluble salts (ii) relative proportion of sodium to other principal cations and (iii) bicarbonate concentration in relation to the concentration of $\mathrm{Ca}^{2+}+\mathrm{Mg}^{2+}$. These have been called as salinity hazard (Wilcox, 1995), sodium hazard and bicarbonate hazard.

The water suitability for irrigation purposes is better adjudged by its sodium hazard potential. This issue is being called sodium absorption ratio (SAR) and expresses the reactions with the soil. The SAR can be computed as follows:

$$
\mathrm{SAR}=\mathrm{Na}^{+} /\left[\left(\mathrm{Ca}^{2+}+\mathrm{Mg}^{2+}\right) / 2\right]^{0.5}
$$

where all ionic concentrations are expressed in milliequivalents per litre (meq/L).

The classification of groundwaters from the Oban massif with respect to SAR is presented in Table 5. The waters from the shallow and deep aquifers from both sampling seasons are found to be less than 10 (limit for excellent water classification), thus they are classified as excellent for irrigation.

Deep aquifer waters have sodium contents between of 2.40 and $29.50 \%$ in the wet season and in the range of 2.64 to $25.66 \%$ in the dry season. The sodium contents in waters from shallow aquifers range from 3.60 to $27.53 \%$ and from 2.53 to $19.12 \%$ in the wet and dry seasons, respectively. These results show that the waters from both aquifer types are within excellent $(<20 \% \mathrm{Na})$ to good $(20-40 \% \mathrm{Na})$ category.

All the water types sampled in both seasons plot within the excellent to good field of the Wilcox diagram (Figure $3)$.

\section{Conclusions}

The waters from the shallow and deep aquifers are slightly acidic in the dry season and evolve to a slightly alkaline nature in the wet season. Calcium and magnesium are the dominant cations which are generally higher in the shallow aquifers. Anions such as $\mathrm{Cl}^{-}, \mathrm{SO}_{4}{ }^{2-}, \mathrm{HCO}_{3}{ }^{-}$and $\mathrm{NO}_{3}{ }^{-}$are higher in the deep wells for both sampling seasons. Two types of hydrogeochemical facies were identified in the area: $\mathrm{Ca} / \mathrm{Mg}-\mathrm{HCO}_{3}$ and $\mathrm{Ca} / \mathrm{Na}-\mathrm{Cl} / \mathrm{SO}_{4}$. The water chemistry is influenced by rainfall, weathering processes (mainly silicate weathering) and water mixing. Deductions from SAR and \% $\mathrm{Na}$ calculations as well as the Wilcox diagram, suggest that the waters can be used for irrigation purposes.

\section{References}

Amadi, U. M. P. (1987). Mixing phenomenon in groundwater systems and its relevance in water quality assessment in Nigeria. In: K, Iwugo (ed.) paper presented at the second annual symposium/conference of the Nigerian water and sanitation associated. pp 17.1-17.31.

Ayi, N. E. (1987). Geology and Geochemistry of the Eastern part of the Oban massif. M.Sc Thesis, Dept. of Geology, University of Calabar, Calabar, Nigeria.

CRBD. (2008). Hydrogeological survey of lower Cross River Basin: Final Report. 158p. Cross River Basin Development Authority, Calabar, Nigeria.

Davis, S. N. (1969). Porosity and permeability of natural materials. In: Flow Through Porous Media, De Wiest $R J M$ (ed). New York: Academic Press. pp 53-87.

Davis, S. N., \& De Weist, R. J. M. (1966). Hydrogeology. New York: John Wiley \& Sons.

Edet, A. E. (1993). Hydrogeology of parts of Cross River State, Nigeria: Evidence from Aero-geological and surface resistivities. PhD Thesis, Dept. of Geology, University of Calabar, Calabar, Nigeria.

Edet, A. E., \& Okereke, C. S. (2005). Hydrogeological and Hydrochemical character of the regolith aquifer, northern Obudu Plateau, Southern Nigeria. Hydrogeology Journal, 13, 391-415. http://dx.doi.org/10.1007/s10040-004-0358-9 
Edet, A. E., Okereke, C. S. Teme, S. C. et al. (1998). Application of remote-sensing data to groundwater exploration: A case study of the Cross River State, SE Nigeria. Hydrogeology Journal, 6, 394-404. http://dx.doi.org/10.1007/s100400050162

Edet, A. E., Teme. S. C., Okereke, C. S., et al. (1994). Lineament analysis for groundwater exploration in Precambrian Oban massif and Obudu Plateau, SE Nigeria. Journal of Mining and Geology, 30(1), 87-95.

Ekwere, A. S. (2010). Hydrogeological and Hydrogeochemical Framework of the Oban Massif, south-eastern Nigeria. Ph.D Thesis, Dept. of Geology, University of Calabar, Calabar, Nigeria.

Ekwueme, B. N. (1990). Rb-Sr ages and petrologic features of Precambrian rocks from the Oban massif, south-eastern Nigeria. Precamb. Res., 47, 271-286. http://dx.doi.org/10.1016/0301-9268(90)90042-O

Ekwueme, B. N. (2003). The Precambrian geology and evolution of the Southeastern Nigerian basement complex. Calabar: University of Calabar Press. 135p.

Elueze, A. A., Omidiran, J. O., \& Nton, M. E. (2004). Hydrogeochemical investigation of surface water and groundwater around Ibokun, Ilesha area, southwestern Nigeria. Jour. Min. Geol., 40(1), 57-64.

Hallberg, G. R. (1989). Nitrates in groundwater of United States of America. In R. F. Follet (Ed.). Nitrogen management and groundwater protection: Developments in agriculture and managed forest ecology (pp. 2-21). Dordrecht: Elsevier.

Hem, J. B. (1986). Study and interpretation of chemical characteristics of natural water. US Geological survey water supply paper, 2, 245-263.

Hounslow, A. W. (1995). Water quality data: Analysis and interpretation. CRC Press LLC, Lewis publishers.

Langmuir, D. (1997). Aqueous Environmental Geochemistry. New Jersey: Prentice Hall, Inc. Upper Saddle River. 07458.

Naik, P. K., Awasthi, A. K., Anand, A. V. S. S., et al. (2001). Hydrogeologic framework of the Deccan Terrain of Koyna River Basin, India. Hydrogeology Journal, 9(3), 243-264. http://dx.doi.org/10.1007/s100400100123

Norton \& Knapp. (1977). Transport phenomena in hydrothermal system: the nature of porosity. American Journal Science, 277, 913-936. http://dx.doi.org/10.2475/ajs.277.8.913

Okereke, C. S., Esu, E. O., \& Edet, A. E. (1998). Determination of potential groundwater sites using geological and geophysical techniques in Cross River State, southeastern Nigeria. Jour. of African Earth Sci., 27(1), 149-163. http://dx.doi.org/10.1016/S0899-5362(98)00053-0

Petters, S. W., Adighije, C. I., Essang, E. B., et al. (1989). A Regional Hydrogeological Study of rural water supply options for planning and implementation of phase II rural water programme in Cross River State, Nigeria. Report for Directorate of Rural Development. CRSG, Nigeria.

Rahman, A. A. M. S., Ukpong, E. E., \& Azmatullah, M. (1981). Geology of parts of the Oban massif, southeastern Nigeria. Jour. Min. Geol., 18(1), 60-65.

Scheytt, T. (1997). Seasonal variations in groundwater chemistry near Lake Belau, Schleswig-Holstein, Northern Germany. Hydrogeology Journal, 5(2), 86-95. http://dx.doi.org/10.1007/s100400050123

Sears, S. O., \& Langmuir, D. (1982). Sorption and clay mineral equilibria controls on moisture chemistry in a C-horizon soil. Jour. Hydrol., 56, 287-308. http://dx.doi.org/10.1016/0022-1694(82)90019-1

Tijani, M. N. (1994). Hydrochemical assessment of groundwater in Moro area, Kwara State, Nigeria. Environ. Geol., 24, 194-202. http://dx.doi.org/10.1007/BF00766889

Wilcox, L. V. (1955). Classification and use of irrigation water (US Department of Agriculture Circular 969). US Department of Agriculture, Washington. 
Table 1. Representative aquifer parameters across the Oban massif

\begin{tabular}{|c|c|c|c|c|c|}
\hline $\begin{array}{l}\text { Location /aquifer } \\
\text { depth }\end{array}$ & $\begin{array}{c}\text { Static water } \\
\text { level }(\mathrm{m})\end{array}$ & $\begin{array}{c}\text { Hydraulic } \\
\text { conductivity }\left(\mathrm{m}^{2} / \text { day }\right)\end{array}$ & $\begin{array}{c}\text { Yield } \\
\left(\mathrm{m}^{3} / \text { day }\right)\end{array}$ & $\begin{array}{c}\text { Aquifer } \\
\text { thickness (m) }\end{array}$ & $\begin{array}{l}\text { Transmissivity } \\
\left(\mathrm{m}^{2} / \text { day }\right)\end{array}$ \\
\hline Abbiati / (shallow) & 5.80 & 13.42 & 105.00 & 24.00 & 120.80 \\
\hline Akamkpa / (shallow) & $\begin{array}{c}4.00^{\ddagger} \\
6.00 \\
\end{array}$ & 13.15 & 190.80 & 58.00 & 150.80 \\
\hline Awi / (deep) & $10.50^{+}$ & $\begin{array}{l}13.18^{\dagger} \\
15.00^{\ddagger}\end{array}$ & 216.00 & $\begin{array}{l}55.00^{\dagger} \\
63.10^{*}\end{array}$ & $159.12^{\dagger}$ \\
\hline Mbarakom / (deep) & $9.50^{\ddagger}$ & $10.14^{\dagger}$ & 180.00 & $\begin{array}{l}40.50^{\dagger} \\
45.80^{\ddagger}\end{array}$ & $123.42^{\dagger}$ \\
\hline Mfamosing / (deep) & & $8.53^{\dagger}$ & - & $50.40^{\dagger}$ & $51.00^{\dagger}$ \\
\hline Oban / (shallow) & 4.70 & 12.46 & $\begin{array}{l}164.16 \\
129.60 \\
\end{array}$ & 30.00 & 132.40 \\
\hline Uyanga / (shallow) & $\begin{array}{c}3.89 \\
0.65^{\$}\end{array}$ & - & - & 22.00 & - \\
\hline
\end{tabular}

$\dagger$ Edet and Okereke (2005)

+ Edet et al. (1998)

Table 2. Measured aquifer parameters from the Oban Massif (adapted from Ekwere, 2010)

\begin{tabular}{|c|c|c|c|c|}
\hline Location & SWL (wet) & SWL (dry) & Aquifer layer (m) & Aquifer type \\
\hline Oban 1 & NR & 6.20 & $5-10$ & deep \\
\hline Oban 2 & NR & 3.21 & $2-10$ & deep \\
\hline Abbiati & NR & 5.80 & $3-9$ & deep \\
\hline Aningeje & NR & 6.00 & $5-15$ & deep \\
\hline Camp 4 & 0.00 & 0.48 & NR & shallow \\
\hline New Ndebiji & 0.00 & 0.18 & NR & shallow \\
\hline Iko Essai & NR & 7.00 & $4-20$ & deep \\
\hline Ibogo & NR & 6.80 & $3-27$ & deep \\
\hline Old Netim & NR & 7.00 & $8-27$ & deep \\
\hline Ayaebam & NR & 6.20 & $6-32$ & deep \\
\hline Obung & NR & 5.80 & 4-39 & deep \\
\hline Uyanga 1 & 2.74 & 5.05 & NR & shallow \\
\hline Uyanga 2 & 0.38 & 1.36 & NR & shallow \\
\hline Uyanga 3 & 1.92 & 3.10 & NR & shallow \\
\hline Igbofia 1 & 0.27 & 0.65 & NR & shallow \\
\hline Igbofia 2 & 0.11 & 0.51 & NR & shallow \\
\hline Igbofia 3 & 0.00 & 0.62 & NR & shallow \\
\hline Akamkpa & 1.51 & 3.76 & $3-25$ & deep \\
\hline Obio Ntan & 2.43 & 4.92 & NR & shallow \\
\hline Orida-Iwuru & 0.67 & 1.87 & NR & shallow \\
\hline Ekpri Iko & 0.18 & 0.78 & NR & shallow \\
\hline Mbarakom & 3.82 & 5.34 & NR & shallow \\
\hline Ojor 1 & 2.69 & 5.36 & NR & shallow \\
\hline Ojor 2 & 3.88 & 4.40 & NR & shallow \\
\hline Ojor 3 & 3.60 & 5.67 & NR & shallow \\
\hline
\end{tabular}

SWL stands for Static Water Level (m); NR stands for Not Reported. 
Table 3(a). Results of representative analysis of sampled groundwaters (dry season)

\begin{tabular}{|c|c|c|c|c|c|c|c|c|c|c|c|c|}
\hline Sample Code & Temp. & $\mathrm{pH}$ & $\mathrm{EC}$ & TDS & $\mathrm{Na}^{+}$ & $\mathrm{Ca}^{2+}$ & $\mathrm{Mg}^{2+}$ & $\mathrm{K}^{+}$ & $\mathrm{HCO}_{3}{ }^{-}$ & $\mathrm{SO}_{4}{ }^{2-}$ & $\mathrm{NO}_{3}^{-}$ & $\mathrm{Cl}^{-}$ \\
\hline GWB 1 & 26 & 5.9 & 46.3 & 29.68 & 3.662 & 12.26 & 0.559 & 1.563 & 30.5 & 2.94 & 1.607 & 5.998 \\
\hline GWB 2 & 28 & 5.86 & 38.6 & 24.74 & 4.339 & 35.2 & 5.168 & 3.455 & 97.6 & 30.77 & 5.892 & 5.998 \\
\hline GWB 3 & 27 & 5.92 & 42.2 & 27.18 & 1.989 & 30.15 & 3.604 & 1.915 & 48.8 & 9.091 & 0.003 & 2.496 \\
\hline GWB 4 & 27 & 5.84 & 34.6 & 22.18 & 2.562 & 17.02 & 1.016 & 1.065 & 30.5 & 1.092 & 0.893 & 3.499 \\
\hline GWB 5 & 26 & 5.14 & 326 & 209 & 4.597 & 62.06 & 4.993 & 3.284 & 61.02 & 113.6 & 8.214 & 14.49 \\
\hline GWB 6 & 29 & 5.08 & 250 & 160.3 & 4.603 & 30.12 & 5.198 & 2.999 & 30.5 & 61.54 & 35.18 & 33.96 \\
\hline GWB 7 & 27 & 5.51 & 67 & 42.95 & 4.401 & 30.11 & 0.847 & 1.449 & 73.2 & 564.1 & 47.51 & 56.98 \\
\hline GWB 8 & 29 & 6.02 & 72.4 & 46.41 & 4.237 & 122.1 & 5.337 & 3.211 & 128.1 & 136.4 & 10.89 & 19.49 \\
\hline GWB 9 & 32 & 6.34 & 69.2 & 44.36 & 2.459 & 30.11 & 0.424 & 0.821 & 42.8 & 13.64 & 0.005 & 4.998 \\
\hline GWB 10 & 28 & 5.4 & 77.4 & 49.62 & 3.745 & 20.09 & 2.063 & 0.809 & 18.3 & 5.88 & 11.25 & 9.997 \\
\hline GWB 11 & 29 & 5.87 & 50.6 & 32.44 & 2.957 & 15.19 & 1.789 & 0.912 & 18.4 & 29.41 & 3.571 & 3.994 \\
\hline GWB 12 & 26 & 5.72 & 83 & 53.21 & 9.00 & 13.4 & 4.9 & 2.08 & 12.25 & 1.22 & 21.2 & 21.56 \\
\hline GWW 1 & 26 & 6.34 & 56.2 & 36.03 & 4.124 & 118.4 & 3.498 & 2.174 & 73.2 & 40.91 & 6.255 & 10.52 \\
\hline GWW 2 & 26 & 6.46 & 326 & 20.9 & 4.382 & 104.4 & 5.285 & 4.463 & 122.3 & 45.47 & 45.89 & 32.99 \\
\hline GWW 3 & 28 & 6.06 & 46.4 & 29.74 & 2.939 & 7.273 & 1.369 & 2.997 & 30.5 & 68.18 & 0.535 & 2.056 \\
\hline GWW 4 & 27 & 5.82 & 56.8 & 36.41 & 3.006 & 22.26 & 2.394 & 0.858 & 24.7 & 29.41 & 8.036 & 8.996 \\
\hline GWW 5 & 27 & 5.97 & 454 & 291 & 4.367 & 9.002 & 5.283 & 5.922 & 85.4 & 0.572 & 4.643 & 0.801 \\
\hline GWW 6 & 26 & 6.04 & 474 & 303.9 & 4.244 & 54.13 & 5.586 & 5.172 & 18.5 & 47.06 & 23.04 & 92.97 \\
\hline GWW 7 & 28 & 5.88 & 586 & 375.6 & 4.951 & 22.04 & 5.15 & 1.847 & 18.3 & 43.59 & 40.01 & 22.99 \\
\hline GWW 8 & 27 & 5.56 & 616 & 394.9 & 4.335 & 15.02 & 4.371 & 4.266 & 36.6 & 50.07 & 19.82 & 21.93 \\
\hline GWW 9 & 27 & 5.62 & 622 & 398.7 & 4.274 & 135.2 & 5.281 & 4.953 & 48.8 & 1.282 & 3.143 & 87.47 \\
\hline GWW 10 & 28 & 6.18 & 482 & 309 & 4.553 & 22.05 & 4.424 & 4.548 & 36.8 & 91.18 & 15.71 & 23.49 \\
\hline GWW 11 & 28 & 5.92 & 612 & 392.3 & 4.408 & 18.05 & 4.668 & 4.941 & 54.7 & 117.9 & 19.46 & 17.99 \\
\hline GWW 12 & 26 & 6.79 & 48.8 & 31.28 & 4.38 & 21.15 & 4.007 & 2.262 & 30.5 & 32.35 & 40.89 & 17.05 \\
\hline GWW 13 & 27 & 5.12 & 52.8 & 33.85 & 3.915 & 15.07 & 1.789 & 2.038 & 24.6 & 27.05 & 4.825 & 8.52 \\
\hline GWW 14 & 28 & 5.71 & 24.8 & 15.9 & 1.163 & 15.13 & 0.447 & 1.645 & 24.4 & 5.128 & 0.009 & 3.999 \\
\hline GWW 15 & 27 & 6.86 & 52 & 33.33 & 3.708 & 13.15 & 1.761 & 0.542 & 54.9 & 12.83 & 1.786 & 1.022 \\
\hline
\end{tabular}

Notes: GWB - groundwater from deep aquifers; GWW - groundwater from shallow aquifers

Concentrations in ppm; EC and temperature in $\mu \mathrm{S} / \mathrm{cm}$ and ${ }^{\circ} \mathrm{C}$, respectively 
Table 3(b). Results of representative analysis of sampled groundwaters (wet season)

\begin{tabular}{|c|c|c|c|c|c|c|c|c|c|c|c|c|}
\hline Sample code & Temp. & $\mathrm{pH}$ & $\mathrm{EC}$ & TDS & $\mathrm{Na}^{+}$ & $\mathrm{Ca}^{2+}$ & $\mathrm{Mg}^{2+}$ & $\mathrm{K}^{+}$ & $\mathrm{HCO}_{3}{ }^{-}$ & $\mathrm{SO}_{4}{ }^{2-}$ & $\mathrm{NO}_{3}{ }^{-}$ & $\mathrm{Cl}^{-}$ \\
\hline GWB 1 & 30.4 & 6.96 & 160 & 110 & 4.65 & 7.46 & 1.01 & 1.01 & 72.14 & 36.25 & 0.69 & 128.5 \\
\hline GWB 2 & 28 & 6.74 & 76 & 120 & 5.71 & 26.05 & 3.67 & 4.69 & 97.55 & 24.99 & 0.95 & 256.4 \\
\hline GWB 3 & 28 & 7.02 & 94 & 140 & 2.42 & 12.80 & 0.37 & 2.11 & 52.14 & 15.34 & 0.09 & 56.74 \\
\hline GWB 4 & 27 & 6.27 & 60 & 40 & 2.07 & 8.01 & 0.27 & 0.19 & 24.16 & 175.2 & 0.18 & 27.99 \\
\hline GWB 5 & 29 & 6.32 & 370 & 570 & 4.79 & 18.12 & 2.86 & 4.04 & 58.74 & 98.2 & 1.25 & 98.2 \\
\hline GWB 6 & 28 & 6.29 & 180 & 120 & 5.6 & 11.27 & 1.83 & 0.96 & 18.25 & 18.24 & 2.57 & 149.9 \\
\hline GWB 7 & 28 & 7.12 & 60 & 40 & 4.93 & 7.06 & 0.56 & 1.35 & 36.47 & 27.29 & 0.26 & 232.9 \\
\hline GWB 8 & 26 & 7.86 & 240 & 370 & 5.09 & 42.84 & 1.96 & 1.62 & 94.56 & 145.7 & 10.04 & 187.5 \\
\hline GWB 9 & 28 & 8.65 & 320 & 190 & 2.3 & 8.12 & 0.4 & 0.74 & 67.1 & 839.6 & 8.27 & 123.6 \\
\hline GWB 10 & 28.5 & 7.29 & 430 & 280 & 2.96 & 14.06 & 0.49 & 0.6 & 213.5 & 294.1 & 4.14 & 596.6 \\
\hline GWB 11 & 27 & 7.85 & 180 & 280 & 3.01 & 8.06 & 2.04 & 1.32 & 186.2 & 188.5 & 2.14 & 126.4 \\
\hline GWB 12 & 28 & 7.89 & 120 & 80 & 4.97 & 30.04 & 2.58 & 3.86 & 54.89 & 36.37 & 1.8 & 50.62 \\
\hline GWB 13 & 29 & 6.9 & 310 & 210 & 1.76 & 60.11 & 1.12 & 0.74 & 127.9 & 31.84 & 1.94 & 103.1 \\
\hline GWW 1 & 28.6 & 7.69 & 90 & 60 & 2.45 & 8.03 & 0.32 & 0.99 & 30.41 & 13.64 & 0.48 & 103.5 \\
\hline GWW 2 & 28 & 7.06 & 190 & 130 & 6.7 & 16.03 & 2.69 & 29.81 & 42.63 & 145.5 & 2.88 & 75.48 \\
\hline GWW 3 & 27 & 6.55 & 240 & 370 & 2.72 & 6.04 & 0.74 & 1.21 & 12.62 & 70.21 & 0.23 & 26.74 \\
\hline GWW 4 & 29.4 & 6.45 & 100 & 70 & 4.06 & 18.13 & 1.29 & 32.18 & 48.64 & 45.5 & 0.53 & 105.5 \\
\hline GWW 5 & 30 & 6.76 & 410 & 290 & 6.97 & 22.07 & 3.42 & 30.16 & 66.98 & 120.5 & 3.18 & 130.9 \\
\hline GWW 6 & 28 & 6.82 & 430 & 570 & 5.87 & 67.25 & 2.92 & 28.72 & 24.22 & 82.4 & 11.72 & 180.2 \\
\hline GWW 7 & 29 & 6.64 & 520 & 780 & 6.76 & 28.06 & 3.06 & 32.04 & 12.14 & 98.6 & 7.27 & 194.6 \\
\hline GWW 8 & 28 & 5.88 & 240 & 170 & 4.32 & 11.36 & 1.64 & 3.26 & 24.34 & 84.09 & 1.18 & 104.5 \\
\hline GWW 9 & 27 & 5.94 & 376 & 540 & 4.45 & 97.14 & 2.78 & 3.62 & 21.92 & 57.4 & 0.34 & 126.8 \\
\hline GWW 10 & 28 & 6.7 & 200 & 140 & 5.66 & 15.15 & 2.07 & 9.79 & 36.49 & 59.09 & 1.04 & 48.49 \\
\hline GWW 11 & 27 & 6.48 & 578 & 890 & 5.69 & 13.02 & 1.99 & 10.13 & 48.64 & 86.21 & 1.01 & 33.46 \\
\hline GWW 12 & 28 & 7.06 & 80 & 120 & 5.02 & 16.08 & 0.99 & 3.26 & 28.2 & 18.16 & 8.49 & 28.05 \\
\hline GWW 13 & 28.5 & 7.14 & 120 & 180 & 3.72 & 18.94 & 1.21 & 2.56 & 36.48 & 42.1 & 2.13 & 22.14 \\
\hline GWW 14 & 27 & 7.62 & 580 & 470 & 2.65 & 10.21 & 0.35 & 2.58 & 384.3 & 471.7 & 1.98 & 308.7 \\
\hline GWW 15 & 27.5 & 6.98 & 310 & 480 & 4.02 & 7.66 & 0.61 & 1.02 & 32.14 & 21.22 & 0.63 & 27.29 \\
\hline GWW 16 & 27 & 7.64 & 110 & 80 & 4.41 & 14.22 & 0.72 & 32.18 & 30.48 & 138.6 & 0.73 & 37.99 \\
\hline
\end{tabular}

Notes: GWB - groundwater from deep aquifers; GWW - groundwater from shallow aquifers

Concentrations in ppm; EC and temperature in $\mu \mathrm{S} / \mathrm{cm}$ and ${ }^{\circ} \mathrm{C}$, respectively 
Table 4(a). Descriptive statistics of parameters as measured in the dry season

\begin{tabular}{|c|l|l|l|l|l|l|l|l|l|l|l|l|l|}
\hline $\begin{array}{c}\text { Well } \\
\text { Type }\end{array}$ & Statistics & $\begin{array}{c}\text { Temp. } \\
(\mathrm{C})\end{array}$ & $\mathrm{pH}$ & $\begin{array}{c}\mathrm{EC} \\
(\mu \mathrm{S} / \mathrm{cm})\end{array}$ & $\begin{array}{c}\mathrm{TDS} \\
(\mathrm{ppm})\end{array}$ & $\mathrm{Ca}$ & $\mathrm{Mg}$ & $\mathrm{Na}$ & $\mathrm{K}$ & $\mathrm{SO}_{4}$ & $\mathrm{NO}_{3}$ & $\mathrm{HCO}_{3}$ & $\mathrm{Cl}$ \\
\hline $\begin{array}{c}\text { Shallow } \\
\text { aquifer }\end{array}$ & Min & 26 & 5.12 & 24.8 & 15.9 & 7.27 & 0.447 & 1.163 & 0.542 & 0.572 & 0.009 & 18.3 & 0.801 \\
& Max & 28 & 6.86 & 622 & 398.7 & 135.2 & 5.285 & 4.553 & 5.922 & 117.9 & 45.89 & 122.3 & 92.97 \\
& Mean & 27.06 & 6.02 & 300.65 & 180.2 & 39.49 & 3.69 & 3.92 & 3.24 & 40.86 & 15.60 & 45.61 & 23.52 \\
& $\mathrm{SD}$ & 0.79 & 0.46 & 255.62 & 169.72 & 43.07 & 1.70 & 0.93 & 1.73 & 32.75 & 15.67 & 29.07 & 28.72 \\
\hline Deep & Min & 26 & 5.08 & 34.6 & 22.18 & 12.26 & 0.424 & 1.989 & 0.809 & 1.092 & 0.003 & 12.25 & 2.496 \\
aquifer & Max & 32 & 6.34 & 250 & 209 & 122.10 & 5.377 & 9.0 & 3.455 & 564.1 & 47.51 & 97.60 & 56.98 \\
& Mean & 27.83 & 5.72 & 96.44 & 61.83 & 34.82 & 2.99 & 4.05 & 1.96 & 80.81 & 12.18 & 49.33 & 15.28 \\
& SD & 1.75 & 0.37 & 92.31 & 59.17 & 30.65 & 2.06 & 1.80 & 1.03 & 158.8 & 15.15 & 35.22 & 16.18 \\
\hline WHO & & & $6.5-8.5$ & 1400 & 1000 & 100 & 50 & 200 & 12 & 400 & 50 & & 250 \\
$(2001)$ & & & & & & & & & & & & & \\
\hline
\end{tabular}

Table 4(b). Descriptive statistics of parameters as measured in the wet season

\begin{tabular}{|c|l|l|l|l|l|l|l|l|l|l|l|l|l|}
\hline $\begin{array}{c}\text { Well } \\
\text { Type }\end{array}$ & Statistics & $\begin{array}{c}\text { Temp. } \\
(\mathrm{C})\end{array}$ & $\mathrm{pH}$ & $\begin{array}{c}\mathrm{EC} \\
(\mu \mathrm{S} / \mathrm{cm})\end{array}$ & $\begin{array}{c}\mathrm{TDS} \\
(\mathrm{ppm})\end{array}$ & $\mathrm{Ca}$ & $\mathrm{Mg}$ & $\mathrm{Na}$ & $\mathrm{K}$ & $\mathrm{SO}_{4}$ & $\mathrm{NO}_{3}$ & $\mathrm{HCO}_{3}$ & \multicolumn{1}{c|}{$\mathrm{Cl}$} \\
\hline Shallow & Min & 27 & 5.88 & 80 & 60 & 6.04 & 0.321 & 2.499 & 0.986 & 13.64 & 0.231 & 12.14 & 22.14 \\
aquifer & Max & 30 & 7.69 & 580 & 890 & 97.14 & 3.418 & 6.996 & 32.18 & 471.7 & 11.721 & 66.98 & 308.70 \\
& Mean & 28 & 6.84 & 285.88 & 333.75 & 23.09 & 1.68 & 4.72 & 13.97 & 97.18 & 2.74 & 55.04 & 97.15 \\
& $\mathrm{SD}$ & 0.92 & 0.54 & 176.27 & 262.57 & 24.36 & 1.04 & 1.46 & 13.78 & 107.65 & 3.41 & 88.91 & 79.15 \\
\hline Deep & Min & 26 & 6.27 & 60 & 40 & 7.46 & 0.27 & 1.76 & 0.19 & 24.99 & 0.09 & 24.16 & 50.62 \\
aquifer & Max & 30.4 & 8.65 & 430 & 570 & 60.11 & 3.67 & 5.71 & 4.69 & 839.60 & 10.04 & 213.5 & 596.6 \\
& Mean & 28.07 & 7.17 & 200 & 196.15 & 19.54 & 1.47 & 3.87 & 1.79 & 148.59 & 2.64 & 84.89 & 164.50 \\
& SD & 1.08 & 0.72 & 124 & 149.64 & 16.29 & 1.10 & 1.46 & 1.47 & 224.93 & 3.12 & 59.52 & 146.17 \\
\hline WHO & & & $6.5-8.5$ & 1400 & 1000 & 100 & 50 & 200 & 12 & 400 & 50 & & 250 \\
$(2001)$ & & & & & & & & & & & & & \\
\hline
\end{tabular}

Table 5. Sodium hazard and percent sodium classification of groundwaters from the Oban massif

\begin{tabular}{|l|l|c|c|l|ll|}
\hline \multicolumn{1}{|c|}{ Bore depth } & Season & SAR $(\mathrm{epm})$ & $\% \mathrm{Na}$ & SAR classification & $\%$ Na classification \\
\hline Deep aquifer & Dry & $0.013-0.181$ & $2.64-25.66$ & S1 $(<10)$ Excellent & $<20$ & Excellent \\
& Wet & $0.012-0.221$ & $2.40-29.50$ & S2(10-18) Good & $20-40$ & Good \\
& & & & S3(18-26) Doubtful & $40-60$ & Permissible \\
& & & & S4( $>26)$ Unsuitable & $60-80$ & Doubtful \\
Shallow aquifer & Dry & $0.013-0.138$ & $2.53-19.12$ & & $>80$ & Unsuitable \\
& Wet & $0.019-0.163$ & $3.60-27.53$ & & & \\
\hline
\end{tabular}




\section{$5^{\circ} 45^{\prime} \mathrm{N}$}

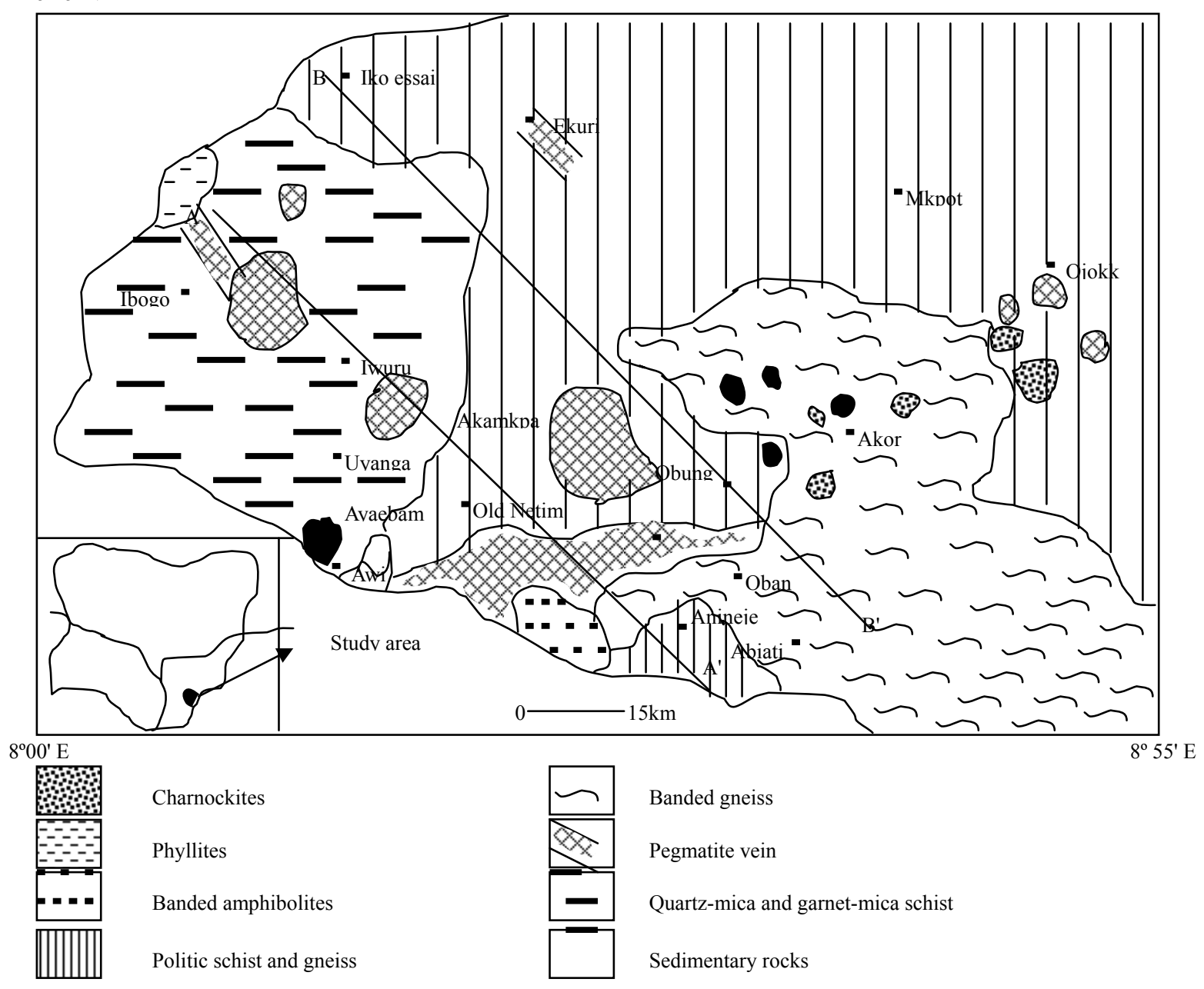

Figure 1. Schematic geological map of the study area (Oban massif): inserted is the map of Nigeria (modified from Ekwueme, 2003) 


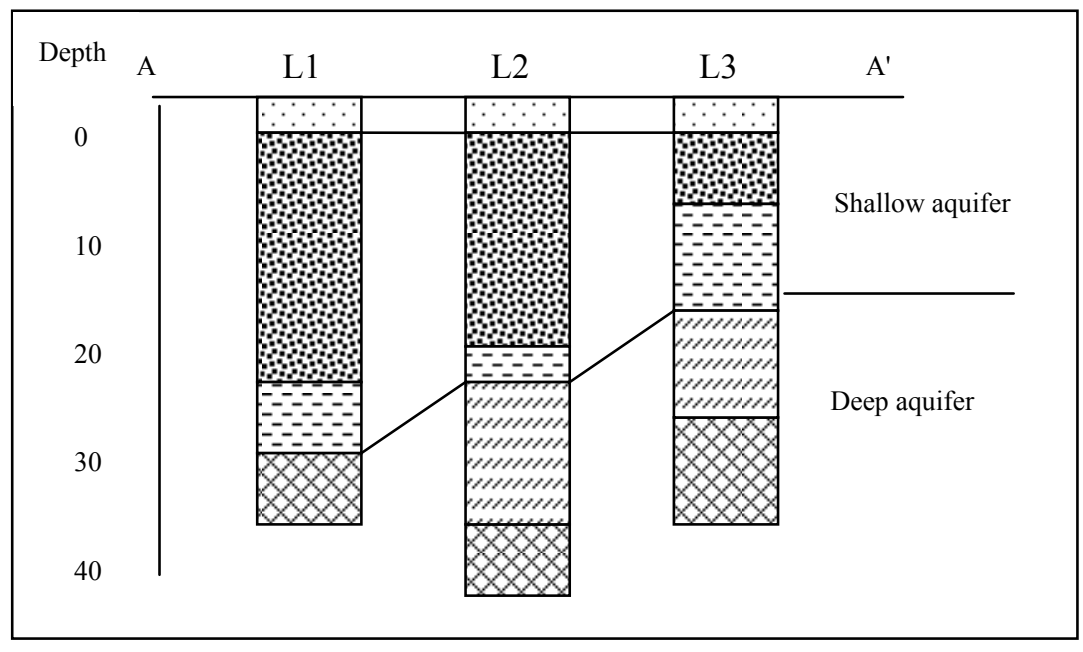

L1- Ibogo, L2- Ayaebam, L3- Abbiati

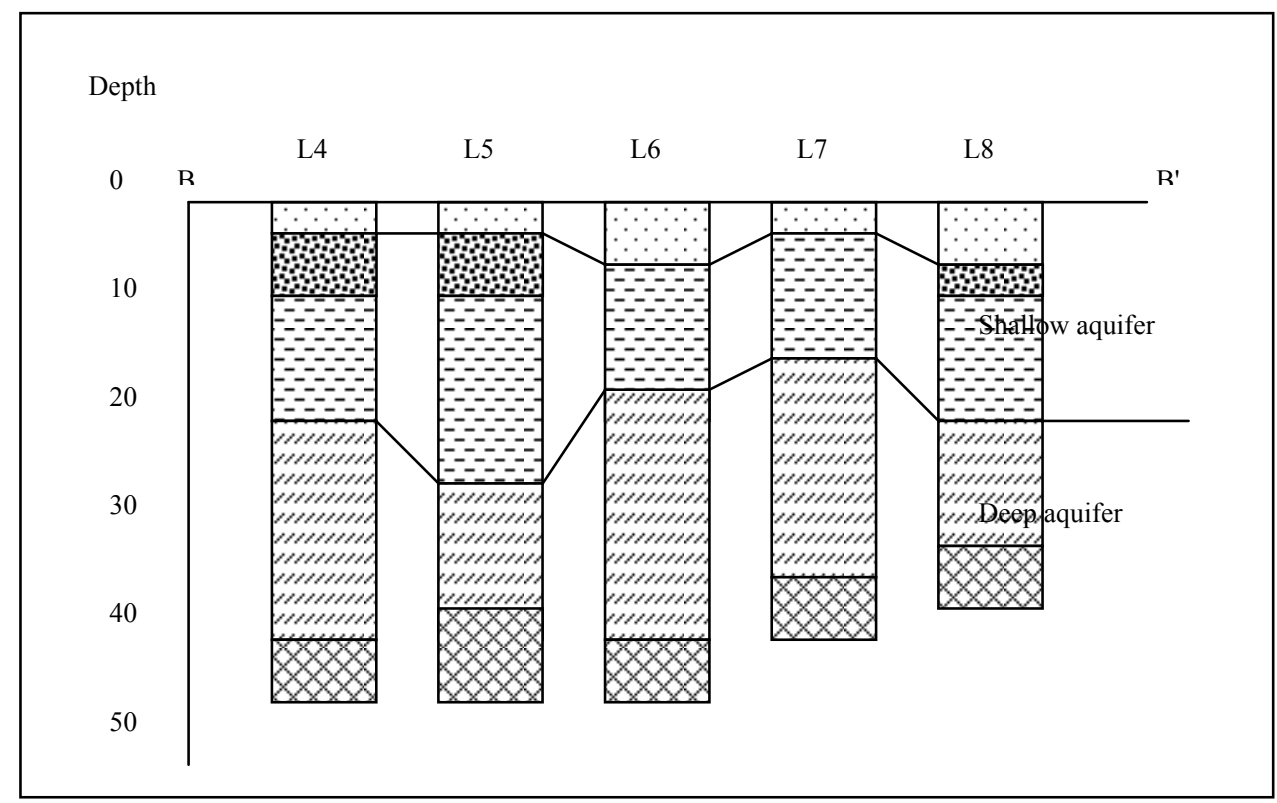

L4- Iko Essai， L5- Old Netim, L6- Obung, L7- Oban, L8- Aningeje Explanation:

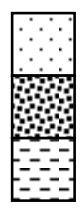

Sand and clay (lateritic)

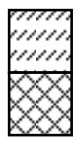

Slightly fractured

Highly weathered

Fresh bedrock

Highly fractured/slightly

Boundary of aquifer unit

Figure 2. (a) Cross section of drilled wells (section A-A') and (b) cross section of drilled wells (section B-B') 


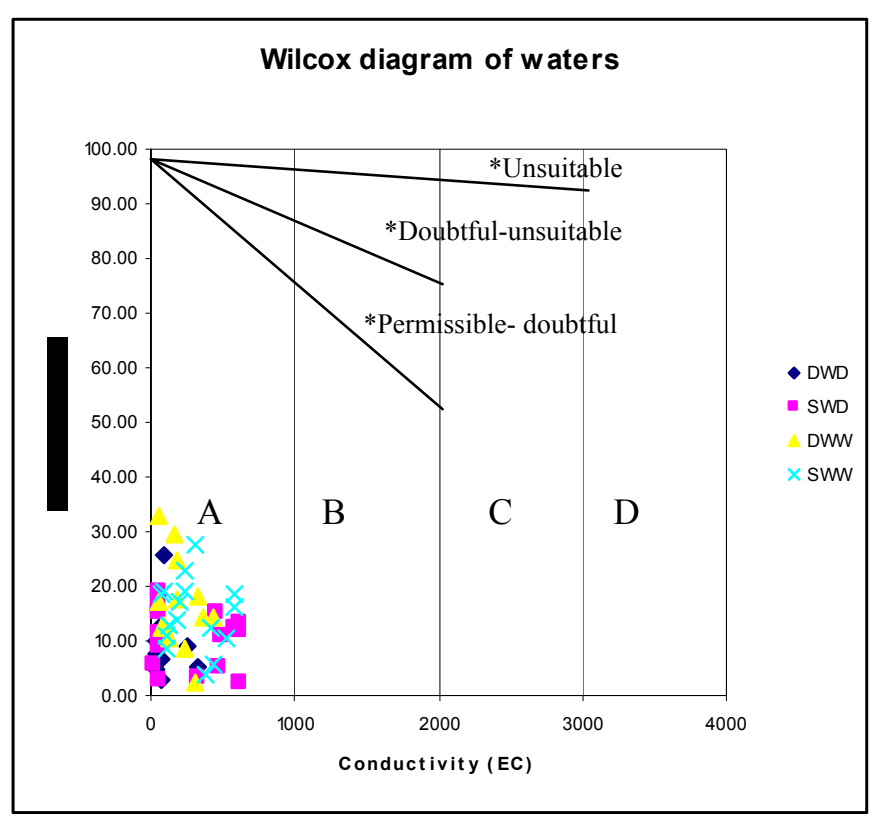

Field: A - excellent to good, B - good to permissible, C - doubtful to unsuitable, D - unsuitable DWD - deep groundwater / dry season; SWD - shallow groundwater / dry season DWW - deep groundwater / wet season; SWW - shallow groundwater / wet season

Figure 3. Wilcox diagram for the groundwaters from the Oban massif 